\title{
Pilot-scale production of the rotifer Brachionus sp. under different culture systems
}

\author{
Producción piloto del rotífero Brachionus sp. bajo diferentes sistemas de cultivo
}

\section{Angel Humberto Rojo-Cebreros ${ }^{1}$, Leonardo Ibarra-Castro ${ }^{1 *}$, Ernesto Guerrero-Carlock ${ }^{1}$, Juan Luis Sánchez-Téllez ${ }^{1}$ and Luis Alvarez-Lajonchère ${ }^{2}$}

\begin{abstract}
${ }^{1}$ Laboratory of Reproduction and Marine Finfish Hatchery, Centro de Investigación en Alimentación y Desarrollo (CIAD), A.C., Unidad Mazatlán, Avenida Sábalo Cerritos S/N, Mazatlán, C.P. 82000, A.P. 711, Sinaloa, México. *leonardo.ibarra@ciad.mx, leobeis@ hotmail.com

${ }^{2}$ Grupo Piscimar, Calle 41 No. 886, Nuevo Vedado, Plaza, La Habana, 10600, Cuba

Resumen.- Pequeños Brachionus sp. (130-230 $\mu \mathrm{m})$ en 2011-2012 y superpequeños Brachionus sp. (110-140 $\mu \mathrm{m})$ en 2013-2014, se cultivaron en un sistema por lotes (ciclos de 3 o 4 días) y en sistemas semi-continuos. Para la alimentación de rotíferos se usaron microalga concentrada (Nannochloropsis sp.), dosificada continuamente con una bomba peristáltica. Las condiciones del cultivo fueron provistas con aire, oxígeno e hidroximetanosulfonato de sodio. La producción total promedio por día fue 552, 602 y 459 millones de rotíferos $\mathrm{d}^{-1}$, con una densidad final promedio de cosecha de 1.099 rotíferos $\mathrm{mL}^{-1}, 1.052$ rotíferos $\mathrm{mL}^{-1}$ y 1.015 rotíferos $\mathrm{mL}^{-1}$, para tres días (3-d), cuatro días (4-d) del sistema de producción por lotes y el sistema de producción semi-continuo, respectivamente. Los valores promedios producidos de rotíferos fueron adecuados para suplir los requerimientos de rotíferos en los ciclos de cultivos piloto, para producir $169 \times 10^{3}$ /año (2012) a $564 \times 10^{3}$ (2013) juveniles/año con una demanda media anual de 83,9 $\times 10^{6}$ rotíferos/1000 juveniles producidos. Los costos totales operacionales por millón de rotíferos/día fueron bajos con el sistema de cultivo semi-continuo $(\$ 0,23)$, seguido por el sistema por lotes de $4-d(\$ 0,55)$ y el sistema por lotes de $3-d(\$ 0,59)$. Estos costos de producción fueron más bajos que otros reportes de producción con alimento artificial y sistemas de recirculación. Los principales componentes de los costos operacionales fueron alimento (71-77\%) y personal (7-11\%). La mejor estabilidad y confiabilidad de la producción fue con el sistema semi-continuo, el cual garantizó las cantidades requeridas diariamente para los cultivos de cría larval más altos. Para posibles mejoras y aumento de la producción, la discusión se basa en términos de eficiencia financiera.
\end{abstract}

Palabras clave: Sistema de cultivo por lotes, sistema de cultivo semi-continuo, análisis de costos operacionales, larva de peces marinos

Abstract.- Small Brachionus sp. (130-230 $\mu \mathrm{m})$ in 2011-2012 and tiny Brachionus sp. (110-140 $\mu \mathrm{m})$ in 2013-2014 were reared in batch culture ( 3 or 4 day cycles) and semi-continuous systems. For feeding rotifers, nonviable microalgae (Nannochloropsis sp.) were used and were continuously dosed with peristaltic pumps. The cultures provided air, oxygen, and sodium hydroxymethanesulfonate. An average total daily production of 552, 602 and 459 million rotifers $d^{-1}$ with mean final densities of 1,099 rotifers $\mathrm{mL}^{-1}, 1,052$ rotifers $\mathrm{mL}^{-1}$ and 1,015 rotifers $\mathrm{mL}^{-1}$ were harvested in three day (3-d) and four day (4-d) batch culture systems and semi-continuous culture systems, respectively. The average values of rotifers produced were adequate to supply the rotifers required in the parallel pilot rearing larval cycles, and $169 \times 10^{3} / \mathrm{yr}$ (2012) to $564 \times 10^{3}$ (2013) juveniles/yr were produced with a mean annual demand of $83.9 \times 10^{6}$ rotifers $/ 1,000$ juveniles produced. The total operational cost per million rotifers/day was lower for the semi-continuous culture system $(\$ 0.23)$, followed by the $4-d$ batch system $(\$ 0.55)$ and 3-d batch system $(\$ 0.59)$. These production costs were lower than those of other reports with artificial feeds and recirculation systems. The main components of the total operational cost was food (71-77\%) and labor (7-11\%). The best production stability and reliability were in the semicontinuous system, which best met the required daily quantities for the larval rearing trials. For possible improvements and increased production, the results are discussed in terms of financial efficiency.

Key words: Batch culture system, semi-continuous culture system, operational cost analysis, marine fish larvae

\section{INTRODUCTION}

There are no efficient dried diets for the initial feeding of marine and estuarine fish larvae. Often, the larvae have small mouths; therefore, growers use small rotifers as the first feed (Su et al. 1994, Duray et al. 1996, Leu et al. 2003). Thus, marine- estuarine pilot and commercial scale hatcheries need to produce significant quantities of high quality rotifers at the right time. The challenge is meeting the larval rearing demands with longstanding, flexible and reliable production systems and 
acceptable financial efficiency costs (Hagiwara et al. 2001). This is essential for juvenile mass production stability.

The first system developed in the 60s was a semi-intensive batch culture system that reached $\sim 200$ rotifers $\mathrm{mL}^{-1}$ (Hirata 1980, Lubzens 1987) and was the basis for the semi-intensive and semi-continuous system, which can produce up to 300 rotifers $\mathrm{mL}^{-1}$ (Fukusho 1989). In more recent years, full-grown intensive and semi-continuous systems that can reach densities of $\sim 7,000$ to 30,000 rotifers $\mathrm{mL}^{-1}$ have been used (Yoshimura et al. 1997, Suantika et al. 2001, 2003; Rombaut et al. 2003, Bentley et al. 2008), some with a much higher density of 160,000 rotifers $\mathrm{mL}^{-1}$ (Yoshimura et al. 2003).

Batch culture systems require several tanks that are harvested at certain time intervals and require increased space and labor, and the results can be unstable and unpredictable (Dhert et al. 2001). One of the important causes of instability of the batch culture system is the water quality of the culture, together with pathogenic bacteria present in the tanks (Dhert et al. 2001, Rombaut et al. 2001). Water quality is improved with semicontinuous systems using microalgae and yeast, without water flow (Lubzens 1987), and the systems are further improved with recirculation (Suantika et al. 2003).

The tendency of marine and estuarine larval rearing protocols is toward intensive culture; therefore, the demand for rotifers has also increased. For example, the production of one ton (fresh weight) of rotifers ( $400 \times 10^{9}$ rotifers $)$ is required to produce 10 million juveniles of the gilthead seabream (Sparus aurata) in the Mediterranean region (Zmora et al. 1991). In this context, we designed a pilot-scale plant for research and technology development regarding marine and estuarine juvenile mass production (Alvarez-Lajonchère et al. 2007). The plant was built at the Mazatlan unit of the Centro de Investigación en Alimentación y Desarrollo (CIAD-Mazatlan), with an estimated maximum daily rotifer production of $2.5 \times 10^{9}$ (AlvarezLajonchère et al. 2007). An intensive batch system was the first culture adopted, using dry diets (Alvarez-Lajonchère \& Sánchez-Téllez 2013); the system was evaluated in a single trial.

The object of the present study was to assess the efficiency and operational costs of three new small rotifer production systems in the plant using nonviable microalgae (Nannochloropsis sp.): a 1) three day (3-d) batch culture, 2) four day (4-d) batch culture and 3) semi-continuous culture system. With this design, attempts were made to avoid the microalgae production facility and pollution in the rearing environment by dry diets, working without water flow or recirculation. The goal was to select a system that could reach at least 1,000 rotifers $\mathrm{mL}^{-1}$ or higher in 1,000-L tanks to feed the daily demands of spotted rose snapper (Lutjanus guttatus) pilot-scale larval rearing with production stability, reliability and low operational costs.

\section{MATERIALS AND METHODS}

This research was conducted in the marine and estuarine fish pilot-scale plant at the Mazatlan unit (CIAD-Mazatlan) in parallel with spotted rose snapper juvenile production cycles between 2011 and 2014.

\section{ROTIFER STRAINS}

The research experiments used two small Brachionus sp. rotifers strains. First, during 2011 and 2012, the cultured strain was a small one (130-230 $\mu \mathrm{m}$ lorica length) used in the earlier work in the pilot-scale plant. Second, during 2013 and 2014, the technicians of the pilot-scale plant isolated a smaller strain (110$140 \mu \mathrm{m})$ from the mud bottom. The maintenance system for both strains followed Velasco-Blanco et al. (2011).

\section{Culture systems}

Two different phases for the experiments were defined. The first phase was to set up a semi-automatic batch culture system to reach 900-1,000 rotifers $\mathrm{mL}^{-1}$. In the second phase, a semiautomated and semi-continuous system was developed, reaching 1,000-1,500 rotifers $\mathrm{mL}^{-1}$ with daily harvests between 10 and $25 \%$ of the culture volume, without flow or recirculation in the systems. Nonviable microalgae (Nannochloropsis sp.) were used to feed rotifers. Table 1 describes the main facilities and equipment used according to their use in each system. During 2011, the batch culture systems were used. Rotifer rearing took place in 1,200-L white fiberglass cylindroconical tanks supplied with constant aeration, pure oxygen, and feed. The temperature of the seawater was $28 \pm 2^{\circ} \mathrm{C}$ with a salinity of $30 \pm 3$, and the water was treated as described by Alvarez-Lajonchère et al. (2007).

The batch culture system was kept at a constant volume of 1,000-L, reaching a density of $\sim 1,000$ rotifers $\mathrm{mL}^{-1}$ before harvest. The system ran on 3-d or 4-d cycles. One tank was harvested every day at the end of the cycle and another started the new cycle, using a portion of the harvested rotifers $(\sim 500$ millions). The total daily harvests were divided to cover the required quantity in the spotted rose snapper larval rearing tanks and for other research experiments. The mean stocking density for the 3 -d batch culture system was $570 \pm 90$ rotifers $\mathrm{mL}^{-1}$, and $492 \pm 55$ rotifers $\mathrm{mL}^{-1}$ were used for the 4 -d batch culture system. 
Table 1. Results of rotifer production with the three culture systems (mean $\pm \mathbf{s d}$ ) / Resultados de la producción de rotiferos con los tres sistemas de cultivo (promedio \pm desviación estándar)

\begin{tabular}{cccccccccc}
\hline Year & $\begin{array}{c}\text { No of } \\
\text { cycles }\end{array}$ & $\begin{array}{c}\text { Days } \\
\text { per } \\
\text { cycle }\end{array}$ & $\begin{array}{c}\text { Mean daily } \\
\text { density } \\
\text { (rotifer/mL) }\end{array}$ & Fertility (\%) & $\begin{array}{c}\text { Total rotifer } \\
\text { harvested } \\
\left(\times 10^{6}\right)\end{array}$ & $\begin{array}{c}\text { Mean } \\
\text { rotifer } \\
\text { harvested } \\
\left(\times 10^{6}\right)\end{array}$ & $\begin{array}{c}\text { Rotifer used for } \\
\text { larval rearing } \\
\left(\times 10^{6}\right)\end{array}$ & $\begin{array}{c}\text { Juveniles } \\
\text { produced }\end{array}$ & $\begin{array}{c}\text { Rotifers } \\
\text { per } 1000 \\
\text { juveniles } \\
\left(\mathrm{x} 10^{6}\right)\end{array}$ \\
\hline A) $2011^{*}$ & 45 & 3 & $1,163.0 \pm 252.3$ & $24.0 \pm 7.90$ & 24,838 & 552 & 16,419 & 31,954 & 513.83 \\
B) $2011^{*}$ & 35 & 4 & $1,128.0 \pm 118.7$ & $19.9 \pm 7.5$ & 21,071 & 602 & 14,796 & 40,326 & 366.91 \\
C) $2011^{* *}$ & 3 & 10 & $866.0 \pm 214.92$ & $20.7 \pm 9.9$ & 5,880 & 196 & 10,674 & 96,707 & 110.37 \\
$2012^{* *}$ & 3 & 24 & $882.6 \pm 138.47$ & $1.6 \pm 5.9$ & 15,373 & 167 & 15,373 & 169,825 & 90.52 \\
$2013^{* *}$ & 2 & 50 & $931.8 \pm 100.00$ & $18.4 \pm 6.8$ & 45,928 & 459 & 45,928 & 563,562 & 81.50 \\
$2014^{* *}$ & 2 & 50 & $1,014.9 \pm 148.36$ & $17.9 \pm 7.0$ & 31,875 & 318 & 31,875 & 309,883 & 102.86 \\
\hline
\end{tabular}

*Batch culture system, **Semi-continuous system

NOTE: Rotifers used for larval rearing (x $10^{6}$ ) in cycle C) 2011, were complemented with the production from cycle B) 2011

During the 2011 and 2012 seasons, a nonviable Nannochloropsis sp. was used to feed the rotifers (Rotigrow plus ${ }^{\circledR}$ from Reed Mariculture Inc., USA). The supply rate was 1.5 to $2.0 \mathrm{~mL} / \mathrm{million}$ rotifers/day, according to the provider recommendations; the feed was supplied with peristaltic pumps (Uni-dose model U041-281TT, 5 L/h) (De Wolf et al. 1998). Pure oxygen was supplied from a Dewar $130 \mathrm{~m}^{3}$ tank. Organic matter was collected with two devices, a sphere within the water column and another at the water surface with an air-lift system (Schipp et al. 2007). Sodium hydroxymethanesulfonate (ClorAm-X ${ }^{\circledR}$, AquaScience Research Group, Inc., USA) was supplied according to Riche et al. (2006) and Bentley et al. (2008).

For the semi-automated and semi-continuous systems tested in the present study, harvests were performed daily, allowing for partial extraction of the culture media, which was replaced with new water (Fukusho 1989). The extracted volume ( 10$25 \%$ ) depended on the rotifer reproduction rate (\% fertility) and demand of the larval rearing tanks. The stocking density was, in 2013, $922.7 \pm 86.06$, and in 2014, 1,037 \pm 109.01 rotifers $\mathrm{mL}^{-1}$ in 1,000-L. This system was tested in 10-d, 24-d, and 50-d of continuous culture.

For this semi-continuous system new equipment and materials were used, in addition to those used with the batch culture systems (Table 1). This included a new oxygen supply (Respironics Milenium, Philips Model M10, with a capacity of $10 \mathrm{~L} / \mathrm{min}$,), ultra-filter equipment $0.2 \mu \mathrm{m}$ (FreshPoint ${ }^{\mathrm{TM}} \mathrm{U} 440$ Pentek) and calorimetric pump for temperature control of the rearing room (Fan \& Coil, Heat Pump, model 4TWR592e with a cooling capacity of 24,000 BTU and a heat pump, model MWD 516 D1, with a nominal capacity of 2 tons). Rotigrow plus ${ }^{\circledR}$ was replaced with Nano $3600^{\mathrm{TM}}$ (Reed Mariculture Inc., USA). The supply rate was $1.5 \mathrm{~mL} / \mathrm{million}$ rotifers/day, according to the provider recommendations. Rectangular Scotch-Brite ${ }^{\circledR}$ fibers were submerged as a new organic matter traps (Lubzens et al. 2001).

\section{DAILY GROWTH}

Before the daily harvest, the rotifer density in each tank was estimated, taking three $0.5-\mathrm{mL}$ subsamples from a first sample of $200 \mathrm{~mL}$ using a micropipette (Transferpette brand, 100$1,000 \mu \mathrm{L})$. In a Sedgewick Rafter counting chamber, the live rotifers were observed, and they were counted, after fixation with two drops of lugol solution, under a microscope (Leica DM500, EZ Tube ${ }^{\mathrm{TM}}$ ). The rotifers were not counted when they had empty and transparent lorica.

\section{Specific Growth Rate}

The Specific Growth Rate (SGR) from 3-d and 4-d batch culture systems was estimated by the following equation:

$$
\mathrm{SGR}=\frac{\ln \mathrm{Nt}-\ln \mathrm{No}}{t}
$$

where $\mathrm{SGR}=$ specific growth rate, $\mathrm{Nt}=$ rotifer concentration at time $t, \mathrm{No}=$ rotifer concentration at time 0 (stocking) and $t=$ days of culture. 


\section{Fertility}

Fertility (F) was estimated daily, with the same samples used for rotifer culture growth estimation, by the following formula:

$$
\mathrm{F}=\frac{\mathrm{Nt}}{\mathrm{N}} \times 100
$$

where $\mathrm{F}=$ fertility $(\%), \mathrm{Nt}=$ rotifers with at least one egg, $\mathrm{N}=$ total number of rotifers

\section{ECONOMIC AND FINANCIAL ANALYSIS}

Overall calculations were carried out in US dollars (\$, USD), with an exchange rate MXN/USD of \$18.00. Capital costs were different according to the culture system (Table 1). Fixed and variable costs were considered operational costs. The main fixed costs were the annual depreciation of buildings and equipment, estimated according to their useful life and use for rotifer production. The water (seawater and freshwater) volumes and air consumed during rotifer production were estimated according to Ibarra-Castro et al. (2013). Among the variable costs in each system, labor, feed, oxygen, air, electricity and consumables were considered on a monthly basis (Table 2).
Labor was calculated according to the required working hours at a rate of $\$ 1.61 / \mathrm{h}$.

\section{ENVIRONMENTAL PARAMETERS}

Every day at 0800 and $1800 \mathrm{~h}$, the dissolved oxygen concentration (DO, $\mathrm{mg} \mathrm{L}^{-1}$ ), percentage of oxygen saturation $(\%), \mathrm{pH}$, and temperature $\left({ }^{\circ} \mathrm{C}\right)$ were measured with Hach multiparameter equipment (HQ30d, HQd ${ }^{\mathrm{TM}}$ ), while salinity was measured with a refractometer RHS-10ATC. Ammonia was neutralized with ClorAm-X ${ }^{\circledR}$ (Riche et al. 2006, Bentley et al. 2008).

\section{Statistical anAlysis}

The normality and homogeneity of variance for the rotifer density and SGR in batch systems was determined by Shapiro Wilk and Kolmogorov-Smirnov tests, respectively. If data met the requirements for a parametric variance analysis, one-way ANOVA was carried out (Zar 2010). Statistical analyses were performed using the SigmaPlot v11 software $\left({ }^{\odot}\right.$ Systat Software Inc.).

Table 2. Estimated capital investment for rotifer (Brachionus sp.) in three-day (3-d, year 2011) and four-day (4-d, year 2011) batch systems and a semi-continuous system, according to pilot-scale utilization and useful life / Estimación del capital de inversión para la producción de rotíferos (Brachionus sp.) en sistema por lotes de tres días (3-d año 2011), sistema por lotes de cuatro días (4-d, año 2011) y sistema semicontinuo, acorde a su utilización en la escala piloto y vida útil

\begin{tabular}{|c|c|c|c|c|c|c|c|c|c|c|}
\hline \multirow[t]{2}{*}{ Facility } & \multirow[t]{2}{*}{ Item } & \multicolumn{3}{|c|}{ 3-d batch system } & \multicolumn{3}{|c|}{ 4-d batch system } & \multicolumn{3}{|c|}{ Semi-continuous system } \\
\hline & & Quantity & $\begin{array}{l}\text { Annual } \\
\text { cost }\end{array}$ & $\begin{array}{l}\text { Utilization } \\
\text { cost }\end{array}$ & Quantity & $\begin{array}{c}\text { Annual } \\
\text { cost }\end{array}$ & $\begin{array}{l}\text { Utilization } \\
\text { cost }\end{array}$ & Quantity & $\begin{array}{c}\text { Annual } \\
\text { cost }\end{array}$ & $\begin{array}{l}\text { Utilization } \\
\text { cost }\end{array}$ \\
\hline \multirow[t]{3}{*}{ Buildings } & Seawater intake system & 1 & 4,058 & 10.1 & 1 & 5,410 & 13.52 & 1 & 1,352 & 3.40 \\
\hline & Small inoculum room & $10 \mathrm{~m}^{2}$ & 25 & 4 & $10 \mathrm{~m}^{2}$ & 25 & 4 & $10 \mathrm{~m}^{2}$ & 25 & 4 \\
\hline & Rotifer production room & $30 \mathrm{~m}^{2}$ & 25 & 4 & $30 \mathrm{~m}^{2}$ & 100 & 15 & $10 \mathrm{~m}^{2}$ & 15 & 3 \\
\hline \multirow{2}{*}{$\begin{array}{l}\text { Other } \\
\text { installations }\end{array}$} & Seawater treatment room & 1 & 30 & 4.50 & 1 & 40 & 6 & 1 & 21 & 3 \\
\hline & Blower room & 1 & 11.4 & 2 & 1 & 11.4 & 2 & 1 & 11.4 & 2 \\
\hline \multirow[t]{11}{*}{ Equipment } & Seawater pump & 1 & 400 & 100 & 1 & 500 & 125 & 1 & 300 & 75 \\
\hline & Temperature control system & - & - & - & - & - & - & 1 & 167 & 167 \\
\hline & $\begin{array}{l}\text { Seawater treatment and } \\
\text { pipework installations }\end{array}$ & 1 & 2,183 & 546 & 1 & 2,910 & 728 & 1 & 728 & 182 \\
\hline & Ultra-filter & - & - & - & - & - & - & 1 & 222 & 222 \\
\hline & $\begin{array}{l}\text { Freshwater treatment and } \\
\text { pipework installations }\end{array}$ & 1 & 649 & 162 & 1 & 865 & 216 & 1 & 216 & 54 \\
\hline & Blower & 1 & 1,750 & 210 & 1 & 2,333 & 280 & 1 & 583 & 70 \\
\hline & Air pipework installations & & 300 & 75 & & 400 & 100 & 1 & 150 & 38 \\
\hline & $\begin{array}{l}\text { Oxygen system (Dewar } \\
\text { tank) }\end{array}$ & 1 & 111 & 111 & 1 & 167 & 167 & - & - & - \\
\hline & Oxygen concentrator & - & - & - & - & - & - & 1 & 167 & 167 \\
\hline & Laboratory equipment & several & 510 & 255 & several & 510 & 255 & several & 510 & 255 \\
\hline & Peristaltic pump & 3 & 180 & 180 & 4 & 240 & 240 & 1 & 60 & 60 \\
\hline \multirow[t]{3}{*}{ Tanks } & $1,2 \mathrm{~m}^{3} \tan \mathrm{k}$ & 3 & 90 & 90 & 4 & 120 & 80 & 1 & 30 & 30 \\
\hline & $300-\mathrm{L}$ tank & 1 & 45 & 45 & 1 & 45 & 45 & 1 & 45 & 45 \\
\hline & $100-\mathrm{L} \tan \mathrm{k}$ & 1 & 30 & 30 & 1 & 30 & 30 & 1 & 30 & 30 \\
\hline Total capital cost & & & 10,397 & & & 13,706 & & & 4,632 & \\
\hline $\begin{array}{l}\text { Total annual } \\
\text { depreciation }\end{array}$ & & & & $1,828.6$ & & & 2,307 & & & 1,410 \\
\hline
\end{tabular}




\section{Results}

The first phase was to set up a semi-automatized batch culture system. Forty-five cycles were carried out with the 3-d system during 2011, with a total harvest of $16,419 \times 10^{6}$ rotifers (mean of 552 million/day) (Fig. 1A). Thirty-five cycles were carried out with the 4-d system, with a total harvest of 14,796 x $10^{6}$ rotifers (mean of 602 million rotifers/day) (Fig. 1B). The maximum and mean final densities with the 3 - $d$ batch system were 1,600 rotifers $\mathrm{mL}^{-1}$ and 1,099 rotifers $\mathrm{mL}^{-1}$, respectively. By contrast, 1,437 rotifers $\mathrm{mL}^{-1}$ and 1,052 rotifers $\mathrm{mL}^{-1}$ maximum and mean final densities were obtained with the 4-d batch system. From the rotifers produced with the batch systems, a total of 31,215 million were supplied to the larval rearing tanks of the spotted rose snapper, which produced 72,280 45-d juveniles (Table 1).

In the second phase, the semi-automated and semicontinuous system was tested. The semi-continuous system allowed high production stability (Fig. 2). After the initial results with 10-d cycles in 2011 and 24-d cycles in 2012, all other production cycles were carried out for a duration of 50-d in 2013 and 2014. The mean daily production reached 459.3 million in 2013 and 318.8 million in 2014. The mean densities were 931.8 (2013) and 1,014.9 (2014) rotifers $\mathrm{mL}^{-1}$. The highest density achieved in both years was 1,120 rotifers $\mathrm{mL}^{-1}$.
The 45-d juveniles produced were 563,562 in 2013 and 309,883 in 2014 (Table 1). All rotifers produced with the semicontinuous system were used to feed rose spotted snapper larvae, with a total of 1,130 million juveniles produced during those years, fed with a mean of 83.9 million rotifers per 1,000 juveniles (Table 1).

\section{Growth}

Rotifer culture growth per day in the 3-d and 4-d batch systems showed a linear tendency to increase density independent of the duration of the rearing cycle (Fig. 3). Although the mean stocking density of the 3-d system was higher than the 4-d system, there was no significant difference $\left(\mathrm{F}_{(1,79)}=13.33, P>\right.$ $0.05)$. On the third day of culture, the mean density of the $3-d$ system was $1,104 \pm 223$ rotifers $\mathrm{mL}^{-1}$, which was significantly higher $\left(\mathrm{F}_{(1,79)}=31.38, P<0.05\right)$ than the mean density of the 4-d system $\left(873 \pm 127\right.$ rotifers $\left.\mathrm{mL}^{-1}\right)$.

The growth in the semi-continuous system compared with the batch culture system, and due to the different nature of the systems, can only be observed in the daily growth of the culture submitted to daily harvests to cover the demands of the larval rearing tanks (Fig. 2). However, in the 50-d cycles, the density started to decrease and show less stability at end of the third week or at the fourth week (Fig. 2).
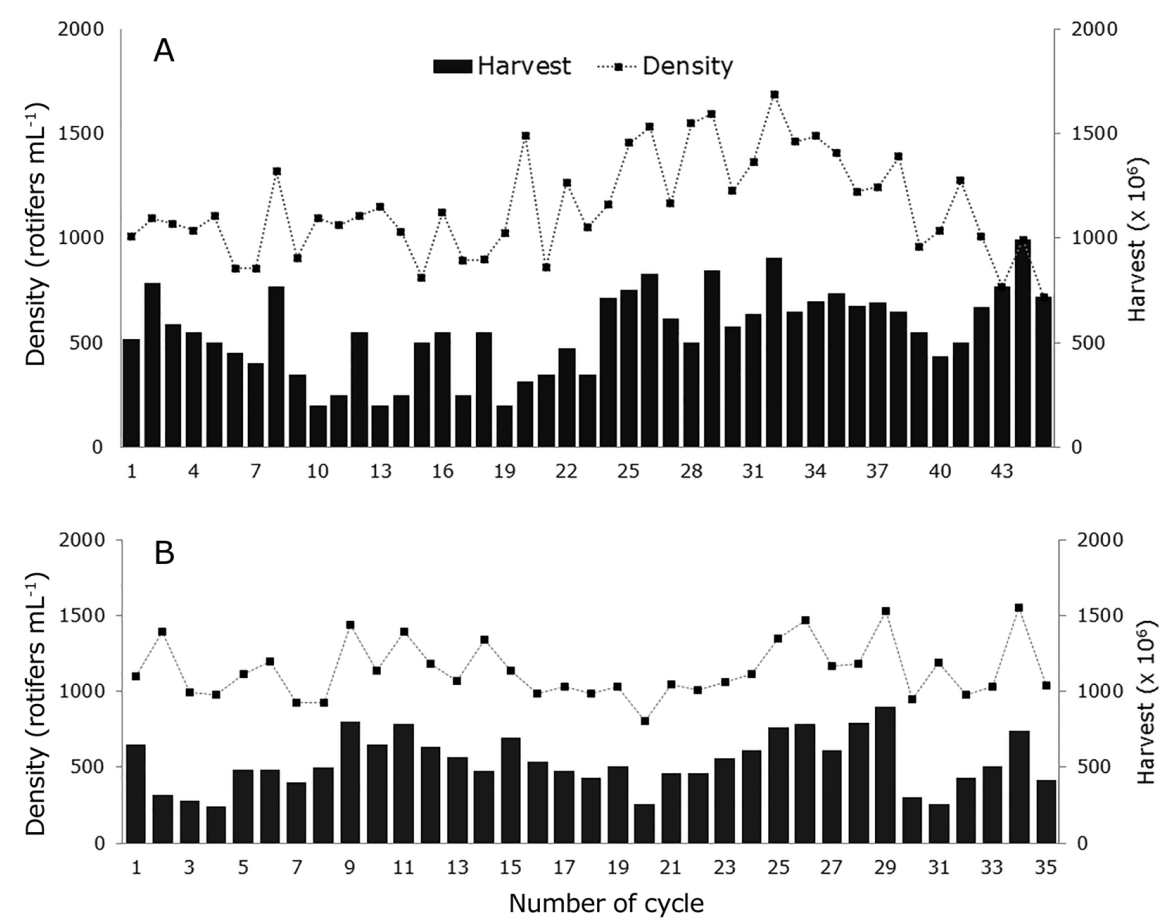

Figure 1. Mean final density per cycle of Brachionus sp. produced in 1,000 L tanks and daily rotifer harvests to supply spotted rose snapper Lutjanus guttatus larvae: A) with the 3-d batch system; B) with the 4-d batch system / Densidad promedio final por ciclo de rotíferos Brachionus sp., producidos en tanques de $1.000 \mathrm{~L}$ y rotíferos cosechados diariamente para suplir las necesidades del cultivo larvario del pargo flamenco Lutjanus guttatus: A) con el sistema de cultivo por lotes de 3-d; B) con el sistema de cultivo por lotes de 4-d 

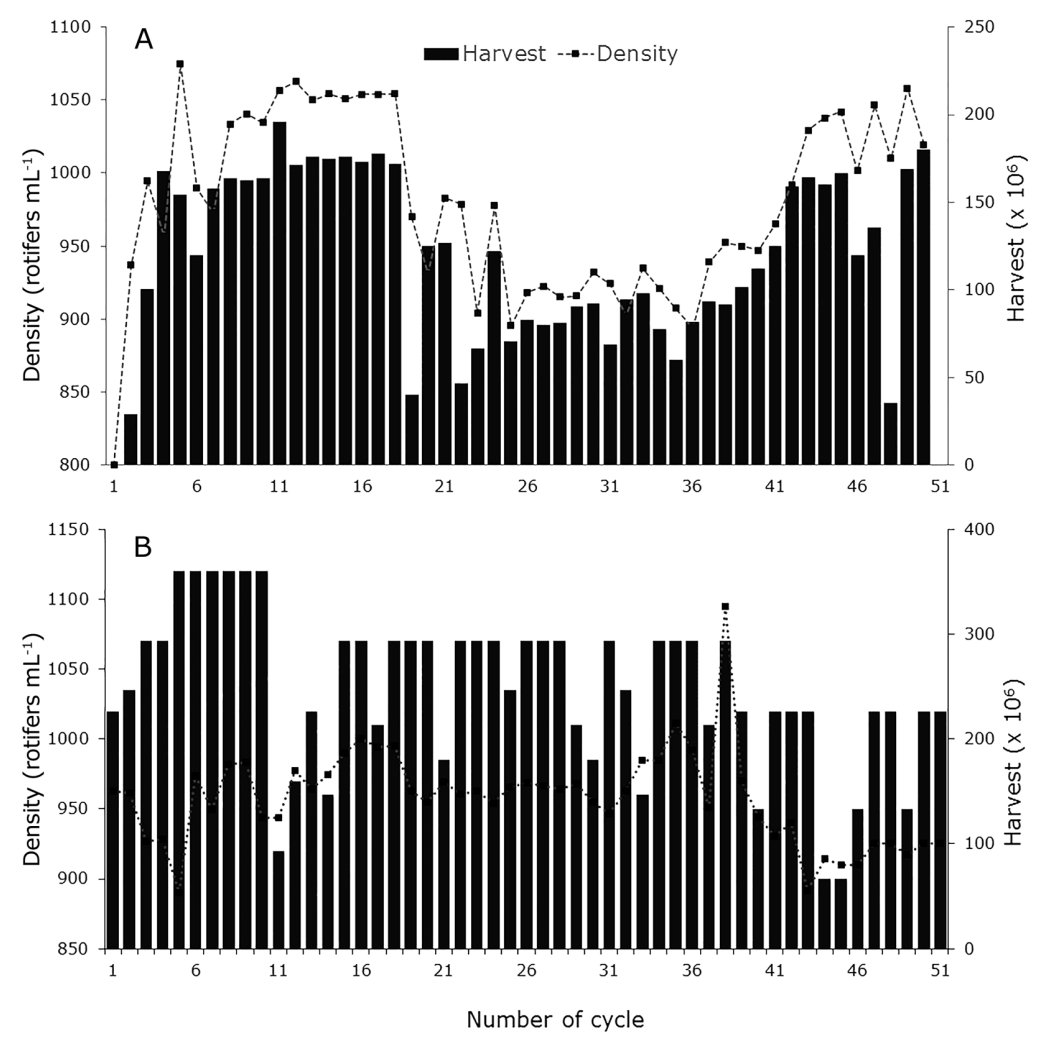

Figure 2. Mean final density per cycle of Brachionus sp. produced with the semi-continuous system in 1,000 Ltanks, and the daily rotifer harvests to supply spotted rose snapper Lutjanus guttatus larvae: A) 2013; B) 2014 / Densidad promedio final por ciclo de rotiferos Brachionus sp., producidos con el sistema semi-continuo en tanques de $1.000 \mathrm{~L}$ y rotíferos cosechados diariamente para suplir las necesidades del cultivo larvario del pargo flamenco Lutjanus guttatus: A) 2013; B) 2014

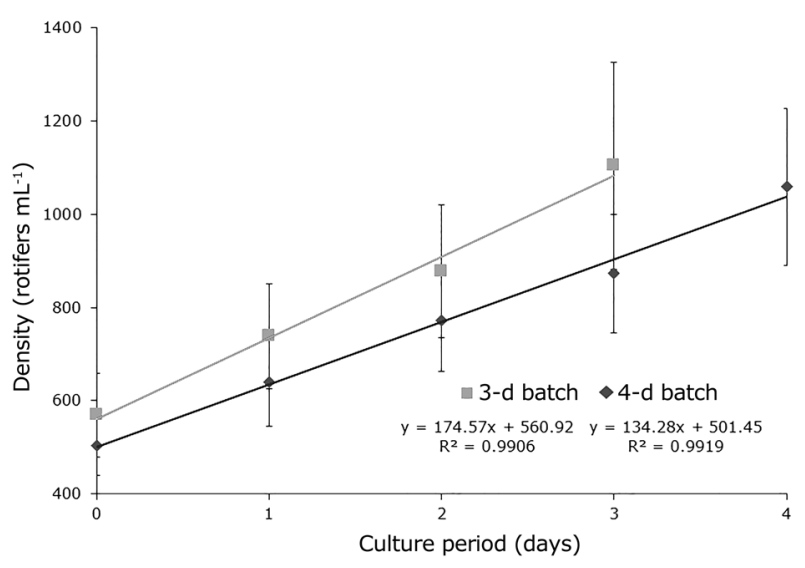

Figure 3. M ean daily growth of Brachionus sp. cultured for 45 cycles with the 3-d batch system and 35 cycles with the 4-d batch system / Crecimiento promedio diario del rotífero Brachionus sp., cultivado durante 45 ciclos con el sistema por lotes de 3-d y 35 ciclos con el sistema por lotes de $4-d$

\section{Specific Growth Rate}

The SGR in the 3-d and 4-d batch system was from 0.12 to 0.26 . The mean lowest values were observed a day before the harvest (Fig. 4). In the 3-d batch system, there was an increase from $0.17 \pm 0.15\left(2^{\text {nd }}\right.$ day $)$ to $0.22 \pm 0.12\left(3^{\text {rd }}\right.$ day $)$ at the harvest day. In the 4-d batch system, the SGR was $0.12 \pm$ 0.14 ( $3^{\text {rd }}$ day) and increased to $0.19 \pm 0.12\left(4^{\text {th }}\right.$ day $)$ at the harvest day. The highest SGR mean occurred in first day of the 3 -d batch system $(0.26 \pm 0.15)$. At the third day of culture, the 3-d batch system and the 4-d batch system showed significant differences $\left(\mathrm{F}_{(1,79)}=12.09, P<0.05\right)$.

\section{Operational cost analysis}

Estimated annual capital costs of facilities and equipment for rotifer production were $\$ 10,397$ for the 3 -d batch system, $\$ 13,706$ for the 4 -d batch system, and $\$ 4,632$ for the semicontinuous system (Table 2). Total operational costs were $\$ 9,780.27, \$ 9,921.41$, and $\$ 3,119.27$ for the 3-d batch, 4-d batch and semi-continuous systems, respectively. In general, 


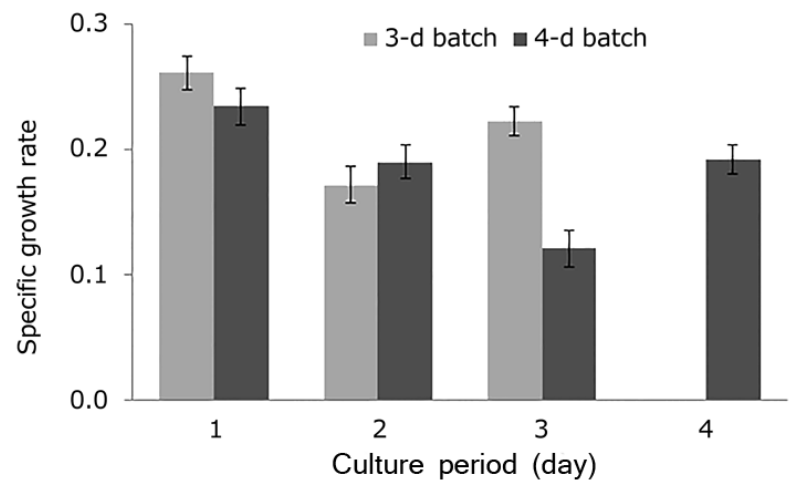

Figure 4. Mean Specific Growth Rates per day of Brachionus sp. for 45 cycles with the 3-d batch culture and 35 cycles with the 4-d batch culture system / Tasa de crecimiento específico promedio por día de Brachionus sp., para 45 ciclos con el sistema por lotes de 3-d y 35 ciclos con el sistema por lotes de 4-d equipment was the most important capital cost, followed by buildings (Table 3 ). The mean monthly depreciation values were \$317.66, \$374.10, and \$153.98 for the 3-d batch, 4-d batch and semi-continuous systems, respectively. Among the operational costs, the most important was feed (70.9-76.5\%), followed by labor (6.8-10.8\%) (Fig. 5). The total cost/million rotifers/day were $\$ 0.59, \$ 0.55$, and $\$ 0.23$ for the 3-d batch, 4-d batch and semi-continuous systems, respectively (Table 4).

\section{ENVIRONMENTAL PARAMETERS}

Dissolved oxygen and oxygen saturation ranged between 8.6$8.7 \mathrm{ppm}$ and $110.3-118.4 \%$ in batch systems, respectively, while it was $10-11 \mathrm{ppm}$ and $115-170 \%$ in the semi-continuous system, respectively. The temperature was between $27^{\circ} \mathrm{C}$ and $29^{\circ} \mathrm{C}$ in all systems, and it was lower and more stable in the semi-continuous system. The $\mathrm{pH}$ was between 7.0 and 7.6 in the batch systems and oscillated approximately 7.5 in the semicontinuous system.

Table 3. Operational cost estimates (USD) by fixed and variable expenditures per month with each of the rotifer (Brachionus sp.) production systems: three day (3-d) batch culture (2011), four day (4-d) batch culture (2011), and a fifty day (50-d) semicontinuous system (2013) applied at a pilot-scale / Estimación de los costos operacionales (USD) de los gastos fijos y variables por mes con cada uno de los sistemas de producción de rotíferos (Brachionus sp.): Sistema por lotes de tres días (3-d) (2011), sistema por lotes de cuatro días (4-d) (2011) y sistema semi-continuo de 50 días (50-d) (2013), aplicados a escala piloto

\begin{tabular}{lrrr}
\hline \multirow{2}{*}{ Item } & 3-d batch & 4-d batch & Semi-continuous \\
\cline { 2 - 4 } & 45 cycles & 35 cycles & Two 50-d cycles \\
\hline Variable costs & & & \\
Labor & 676.67 & 676.67 & 338.33 \\
Electricity & 76.00 & 66.33 & 76.78 \\
Feeds & $7,421.11$ & $7,586.67$ & $2,211.67$ \\
Oxygen & 485.67 & 391.89 & 85.94 \\
Aeration & 2.22 & 1.67 & 1.67 \\
Consumables & 180.34 & 139.45 & 29.70 \\
Repair and maintenance & 170.00 & 230.00 & 80.00 \\
Total variable costs & $9,012.01$ & $9,092.68$ & $2,824.09$ \\
Fixed costs & & & \\
Depreciation & & & \\
$\quad$ Buildings & 24.60 & 40.52 & 15.40 \\
$\quad$ Equipment & 112.82 & 151.73 & 102.10 \\
$\quad$ Total depreciation & 137.42 & 192.25 & 117.50 \\
Administration & 180.24 & 181.85 & 36.48 \\
Total fixed costs & 317.66 & 374.10 & 153.98 \\
Contingency & 450.60 & 454.63 & 141.20 \\
Total operational costs & $9,780.27$ & $9,921.41$ & $3,119.27$ \\
Rotifer production/day $\left(10^{6}\right.$ ) & 552 & 602 & 459 \\
Operational costs/million rotifers/day & 0.59 & 0.55 & 0.23 \\
\hline
\end{tabular}




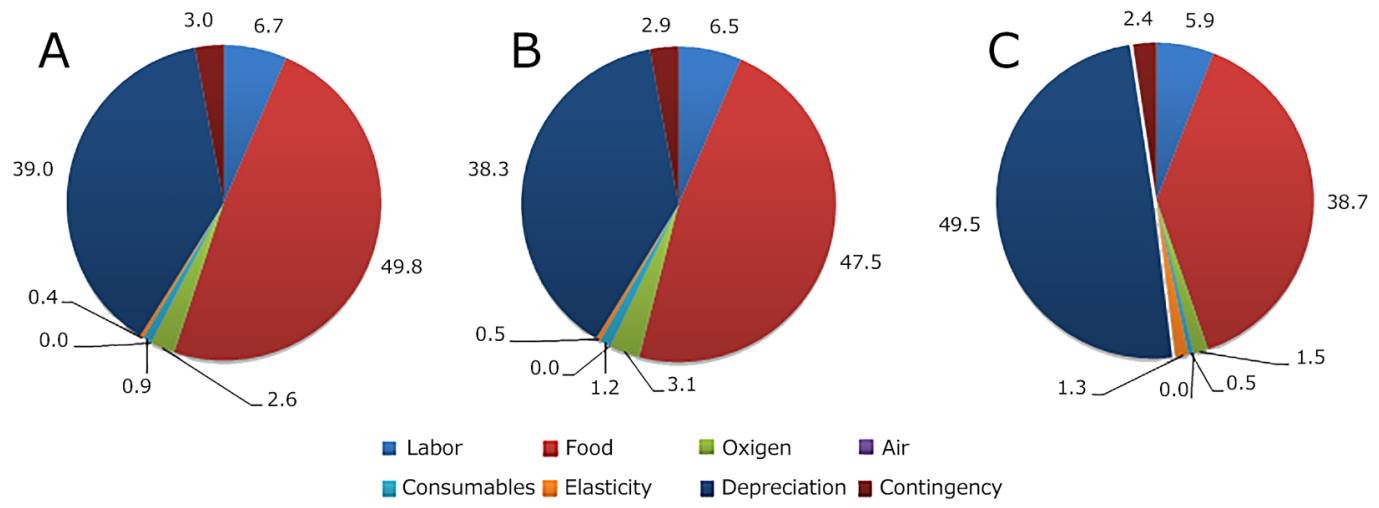

Figure 5. Estimated operational costs (\%) of each Brachionus sp. for the culture systems: A) 3-d batch system; B) 4-d batch system; C) semi-continuous system / Costos operacionales estimados (\%) para cada sistema de cultivo de rotíferos Brachionus sp. Sistema de cultivo: A) sistema por lotes de 3-d; B) sistema por lotes de 4-d; C) Sistema semi-continuo

Table 4. Comparison of other reports similar to the present study / Comparación de otros reportes similares al presente estudio

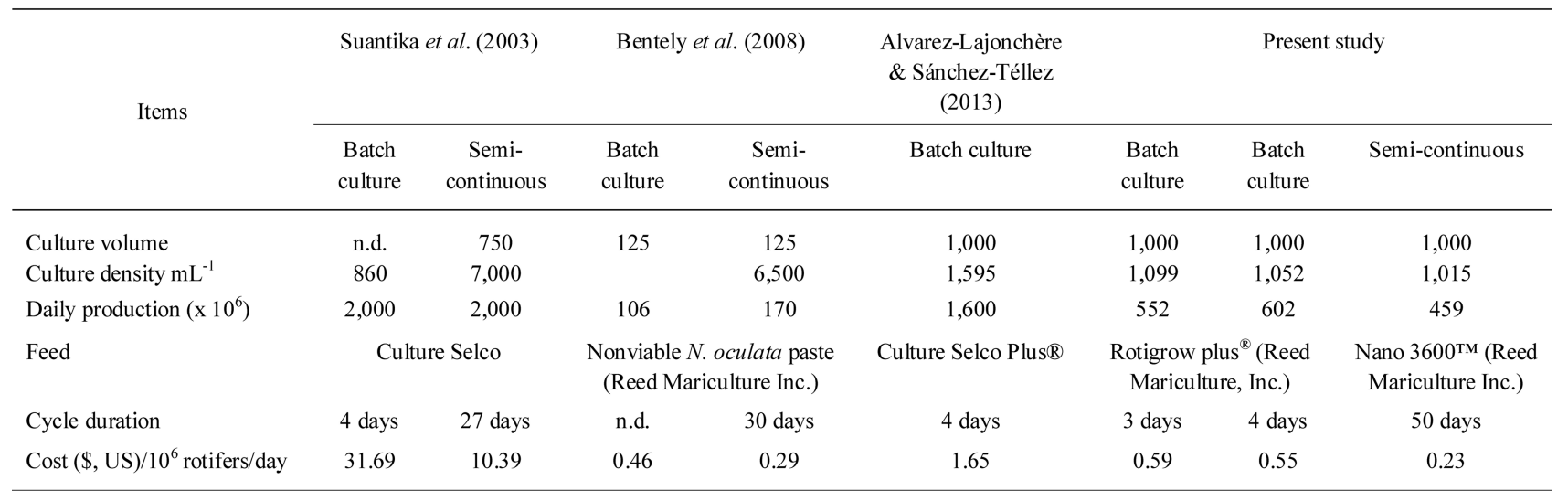

(n.d.) No data available

\section{DisCUSSION}

In marine and estuarine fish hatcheries, it is essential to establish a stable and reliable system for the intensive mass production of rotifers to cover the daily demands of the larval tanks; this organism is the most important live feed for fish larvae (Dhert et al. 2001, Lubzens \& Zmora 2003). Thus, it is necessary to produce rotifers with an efficient and cost-effective system, in the required quantities, of the right sizes, and of high nutritional quality for each larval rearing period (Hagiwara et al. 2001, Alvarez-Lajonchère \& Hernández Molejón 2001).

Recently, efficient semi-continuous culture systems have been developed for rotifer production with recirculation systems. The systems are based on live and concentrated microalgae (Fu et al. 1997, Lubzens et al. 1997, Schipp et al. 2007) or dried feeds (Suantika et al. 2003) with low costs.
When the work with marine and estuarine fishes started in CIAD Mazatlan with experimental facilities, rotifers were cultured with semi-intensive techniques, using live microalgae with 3-d or 4-d batch culture systems. The yields were approximately 140 rotifers $\mathrm{mL}^{-1}$ (Velasco \& Duncan 2002), and the yields later increased to 334 rotifers $\mathrm{mL}^{-1}$ (Guzmán 2004). Later, starting work with the pilot-scale plant (AlvarezLajonchère et al. 2007), a pilot study of intensive culture techniques allowed production yields of 1,595 rotifers $\mathrm{mL}^{-1}$ with Culture Selco plus ${ }^{\circledR}$ (INVE Aquaculture Inc., USA) in 1,000 L tanks and a 4-d batch culture system made in a single cycle (Alvarez-Lajonchère \& Sánchez-Téllez 2013).

In the present study, three production systems, 3-d and 4-d batch and semi-continuous culture techniques, were assessed. For the three systems, the feed source was freeze microalgae, 
following Shipp et al. (2007), although those authors used live frozen Chlorella paste (Super Fresh Chlorella - V12 ${ }^{\circledR}$ ), which was not available to be used in the present study. A nonviable Nannochloropsis sp. had to be used, without the results achieved by the other product (Ibarra-Castro et al. not published). This could influence the results of the present study because rotifers fed with live microalgae have enhanced fertility in comparison with those fed nonviable microalgae or dried feeds.

Although the fertility obtained in this study was $\sim 20 \%$ in the 3-d and 4-d batch culture systems and the semi-continuous 10-d culture, it was lower than that of Chew \& Lim (2005), Alvarez-Lajonchère \& Sánchez-Téllez (2013), and Jabeur et al. (2013). However, when the duration of the production cycles was longer ( 24 and $50 \mathrm{~d}$ ) in the semi-continuous system, the fertility decreased, with mean values of $\sim 15 \%$. This does not occur with live microalgae, and this could show that the environmental conditions and feeding should be improved, as suggested by Delbos \& Schwars (2008).

The fertility and SGR obtained in the present study were lower than dried feeds (Suantika et al. 2003, AlvarezLajonchère \& Sánchez-Téllez 2013) or with live microalgae (Lubzens \& Zmora 2003, Schipp et al. 2007). Yields were between 900 and 1,000 rotifers $\mathrm{mL}^{-1}$, which could be considered admissible for hatcheries in tropical and subtropical regions (Moretti et al. 1999, Alvarez-Lajonchère \& Hernández Molejón 2001, Schipp et al. 2007).

Yoshimura et al. (2003) and Alvarez-Lajonchère \& Sánchez-Téllez (2013) emphasized the importance of controlling water quality. Water quality is essential to maintain high rotifer concentrations. In the present study, these factors were within the adequate range for rotifers, although the rather low fertility could be taken as an indication that some of the factors should be improved in the long cycles with the semicontinuous system.

The three production systems compared in the present study allowed the production of 1,000 rotifers $\mathrm{mL}^{-1}$. The semicontinuous system had better stability, flexibility and reliability, with less labor and consequently lower production cost, in agreement with other reports (Dhert et al. 2001, Suantika et al. 2003, Bentley et al. 2008). Nonetheless, its density was lower than in other reports (Suantika et al. 2003, Bentley et al. 2008). The production covered the rotifer demand from parallel pilot-scale larval rearing, operated at the plant, which reached a maximum production of more than 550,000 45-d juveniles in 2013 and had higher financial benefits.

The usual intensive production systems have two main operational cost items, feed and labor, as in the present study
(Suantika et al. 2003). These systems are characterized by a high cost of equipment (with recirculation systems) and efficient operational costs to reach high densities of $\sim 7,000-8,000$ rotifers $\mathrm{mL}^{-1}$ (Table 4; Suantika et al. 2003, Bentley et al. 2008), much higher than the intensive systems in the present study.

The success in intensive rotifer farming systems have been due to the availability of concentrated microalgae (Yoshimura et al. 1997, 2003; Schipp et al. 2007) and dried commercial diets such as Culture Selco ${ }^{\circledR}$, Selco Plus ${ }^{\circledR}$ and Ori-Culture ${ }^{\circledR}$ (Suantika et al. 2000, 2003; Alvarez-Lajonchère \& SánchezTéllez 2013). These products reduce the production costs of live microalgae, enhance stable and predictable rotifer culture, and provide for the needs of smaller facilities, with fewer supplies and less labor (Suantika et al. 2003, Alvarez-Lajonchère \& Sánchez-Téllez 2013).

In conclusion, total operational cost analysis in the present study showed that the semi-continuous system was the most efficient, even more so than the dried diets tested by Suantika et al. (2003) and Alvarez-Lajonchère \& Sánchez-Téllez (2013). The operational cost could be improved if live microalgae could be produced by a photobioreactor operating in the pilot-plant instead of importing nonviable microalgae. Further improvement could occur if the environmental parameters allowed for an increase in fertility and culture density. Other possible improvements could arise by lowering the salinity to 20-25 and using an open flow or a recirculation system.

\section{ACKNOWLEDGMENTS}

Authors are grateful to National Aquaculture and Fishery Commission (CONAPESCA) in the person of Eng. Francisco Nieto Sánchez, Director of Aquatic and Fishery Development for the confidence and support of research projects between 2011 and 2014. Thanks are also given to the fish pilot-plant personal and to the administration of the Mazatlan Unit of the Centro de Investigación en Alimentación y Desarrollo for their permanent support.

\section{LITERATURE CITED}

Alvarez-Lajonchère L \& OG Hernández-Molejón. 2001. Producción de juveniles de peces estuarinos para un centro en América Latina y el Caribe: diseño, operación y tecnologías, 424 pp. The World Aquaculture Society, Baton Rouge.

Alvarez-Lajonchère L \& JL Sánchez-Téllez. 2013. Análisis financiero de una producción piloto del rotífero, Brachionus rotundiformis, con una dieta artificial. Revista Investigaciones Marinas 33: 2836. 
Alvarez-Lajonchère L, MA Reina-Cáñez, MA CamachoHernández \& S Kraul. 2007. Design of a pilot-scale tropical marine finfish hatchery for a research center at Mazatlan, Mexico. Aquaculture Engineering 36: 81-96.

Bentley CD, PM Carroll, WO Watanabe \& AM Riedel. 2008. Intensive rotifer production in a pilot-scale continuous culture recirculating system using nonviable microalgae and an ammonia neutralizer. Journal of the World Aquaculture Society 39: 625-635.

Chew WYS \& HS Lim. 2005. Some improvements to the rotifer (Brachionus rotundiformis) mass culture method. Singapore Journal Primary Industrie 32 :52-58.

Delbos B \& MH Schwarz. 2008. Rotifer production (as a First Feed Item) for intensive finfish larviculture. Virginia Seafood Agricultural Research and Extension Center, Publication 600-105: 1-3.<https://pubs.ext.vt.edu/600/600105/600-105_pdf.pdf>

De Wolf T, P Candreva, M Dehasque \& P Coutteau. 1998. Intensification of rotifer batch culture using an artificial diet. In: Grizel H \& P Kestemont (eds). Aquaculture and water: Fish culture, shellfish culture and water usage. Abstracts of contributions presented at the International Conference Aquaculture Europe '98, October 7-10, 1998, Bordeaux, France. European Aquaculture Society, Oostende, pp. 6869.

Dhert P, G Rombaut, G Suantika \& P Sorgeloos. 2001. Advancement of rotifer culture and manipulation techniques in Europe. Aquaculture 200: 129-146.

Duray MN, LG Aplazan \& CB Estudillo. 1996. Improved hatchery rearing of mangrove red snapper, Lutjanus argentimaculatus, in larvae tanks with small rotifer (Brachionus plicatilis) and Artemia. The Israeli Journal of Aquaculture, Bamidgeh 48: 123-132.

Fu Y, H Hada, T Yamashita, Y Yoshida \& A Hino. 1997. Development of continuous culture system for stable mass production of the marine rotifer Brachionus. Hydrobiologia 358: $145-151$.

Fukusho K. 1989. Biology and mass production of the rotifer, Brachionus plicatilis (1). International Journal of Fisheries and Aquaculture 1: 68-76.

Guzmán R. 2004. Cultivo experimental del rotífero Brachionus rotundiformis alimentados con una dieta comercial. Bachelor Thesis, Universidad Autónoma de Sinaloa, Facultad de Ciencias del Mar, Mazatlán, 43 pp.

Hagiwara A, WG Gallardo, M Assavaaree, T Kotani \& AB Araujo. 2001. Live food production in Japan: recent progress and future aspects. Aquaculture 200: 111-127.

Hirata H. 1980. Culture methods of the marine rotifer, Brachionus plicatilis. Mini Review and Data File of Fisheries Research / Fisheries Research Laboratory, Faculty of Fisheries, Kagoshima University 1: 27-46.
Ibarra-Castro L, FJ Martínez-Cordero \& L AlvarezLajonchère. 2013. Financial analysis of pilot-scale egg production of Spotted Rose Snapper, Lutjanus guttatus. Aquaculture Economics \& Management 17: 171-183.

Jabeur C, A Merghni \& F Kamoun. 2013. Feeding rotifers Brachionus plicatilis with microalgae cultivated in Tunisia. IOSR Journal of Environmental Science, Toxicology and Food Technology 4: 105-112.

Leu MY, IH Chen \& LS Fang. 2003. Natural spawning and rearing of mangrove red snapper Lutjanus argentimaculatus, larvae in captivity. Bamidgeh 55: 22-30.

Lubzens E. 1987. Raising rotifers for use in aquaculture. Hydrobiologia 147: 245-255.

Lubzens E \& O Zmora. 2003. Production and nutritional value of rotifers. In: Støttrup JG \& LA McEvoy (eds). Live feeds in marine aquaculture, pp. 1-64. Blackwell Science, Oxford.

Lubzens E, G Minkoff, Y Barr \& O Zmora. 1997. Mariculture in Israel-past achievements and future directions in raising rotifers as food for marine fish larvae. Hydrobiología 358: $13-20$.

Lubzens E, O Zmora \& Y Barr. 2001. Biotechnology and aquaculture of rotifers. Hydrobiología 446/447: 337-353.

Moretti A, M Fernandez-Criado, G Cittolin \& R Guidastri. 1999. Manual on hatchery production of seabass and gilthead seabream Vol 1: 1-206. Food and Agriculture Organization of the United Nations, Rome.

Riche M, TJ Pfeiffer \& J Garcia. 2006. Evaluation of a sodium hydroxymethanesulfonate product for reducing total ammonia nitrogen in a small-scale rotifer batch culture system. North American Journal of Aquaculture 68: 199205.

Rombaut G, G Suantika, N Boon, S Maertens, P Dhert, E Top, $P$ Sorgeloos \& W Verstraete. 2001. Monitoring of the evolving diversity of the microbial community present in rotifer culture. Aquaculture 198: 237-252.

Rombaut G, R Grommen, Q Zizhong, V Vanhoof, G Suantika, P Dhert, P Sorgeloos \& W Verstraete. 2003. Improved performance of an intensive rotifer culture system by using a nitrifying inoculum (ABIL). Aquaculture Research 34: 165-174.

Schipp G, J Bosmans \& J Humphrey. 2007. Northern Territory Barramundi Farming Handbook. Fishery Report 89: 1-71, Department of Primary Industry, Fisheries and Mines, Darwin.

Su HM, MS Su \& IC Liao. 1994. Selection of super smallsize strain of the rotifer (Brachionus plicatilis) and its rearing conditions. Journal of Taiwan Fisheries Research 2: 19-29.

Suantika G, P Dhert, M Nurhudah \& P Sorgeloos. 2000. High-density production of the rotifer Brachionus plicatilis in a recirculation system: consideration of water quality, zootechnical and nutritional aspects. Aquacultural Engineering 21:201-214. 
Suantika G, P Dhert, G Rombaut, J Vandenberghe, T De Wolf \& P Sorgeloos. 2001. The use of ozone in a high density recirculation system for rotifers. Aquaculture 201: $35-49$.

Suantika G, P Dhert, E Seetman, E O'Brien \& P Sorgeloos. 2003. Technical and economical feasibility of a rotifer recirculation system. Aquaculture 227: 173-189.

Velasco-Blanco G \& N Duncan. 2002. Cultivo masivo del rotífero Brachionus rotundiformis en un sistema de invernadero como alimento vivo para larvas de peces marinos. VII Congreso Nacional de Ictiología, 18-22 de noviembre de 2002, Puerto Ángel, Oaxaca, México.

Velasco-Blanco G, AC Puello-Cruz, L Alvarez-Lajonchère, B González-Rodríguez, MI Abdo-de la Parra, LE Rodríguez-Ibarra \& A García-Ortega. 2011. Alimento vivo. In Alvarez-Lajonchère L \& AC Puello-Cruz (eds). El pargo flamenco, Lutjanus guttatus. Producción controlada de huevos, larvas y juveniles, pp. 59-97. Centro de Investigación en Alimentación y Desarrollo y AM Ediciones, México.
Yoshimura K, K Usuki, T Yoshimatsu, C Kitajima \& C Hagiwara. 1997. Recent development of a high density mass culture system for the rotifer Brachionus rotundiformis Tschugunoff. Hydrobiologia 358: 139-144.

Yoshimura K, K Tanaka \& T Yoshimatsu. 2003. A novel culture system for the ultra-high-density production of the rotifer, Brachionus rotundiformis -a preliminary report. Aquaculture 227: 165-172.

Zar JH. 2010. Biostatistical analysis, 944 pp. Prentice-Hall/ Pearson, Upper Saddle River.

Zmora O, Y Barr \& A Tandler. 1991. Report on a visit to several European commercial fish hatcheries. Israel Oceanographic and Limnological Research Reports, 63 pp. National Institute of Oceanography (IOLR-NIO), Tel Aviv. 